\title{
Reclaimed Products to Recycling and Energy Recovery for Sustainable Use of Closed Non Sanitary Landfills through Reclamation Works ${ }^{\dagger}$
}

\author{
${ }^{*}$ Byung-Sun Lee, Kyung-Duk Na, Sang-Kuk Han, Chae-Gun Phae and Sae-Eun Oh** \\ FORCEBEL Co., Ltd. \\ *Seoul National University of Science \& Technology, **Hanbat National University
}

\section{요 약}

대전시 $\mathrm{OO}$ 권역 택지발지구내 불법매립지 선별 - 정비사업과정에서 회수된 선별결과물의 재활용성 및 에너지전환 가능성을 평 가하였다. 본 연구에서 사용된 순환형 매립정비시스템(SLR-System, Sustainable Reclamation-System)은 수분함량 약 28.0\%조건에서 약 $91.4 \mathrm{~m}^{3} / \mathrm{hr}$ (about $130.61 \mathrm{ton} / \mathrm{hr}$ )의 처리 성능을 보였으며, 선별결과물의 회수율과 순도는 선별토사가 약 $98.9 \%$ 와 약99.66\%, 선별 가연물류가 약 $91.8 \%$ 와 약 $92.0 \%$ 로 각각 측정되었다. 특히, 선별토사의 경우, 입도크기가 $\varnothing 35 \mathrm{~mm}$ 이하로 유기이물질 함량이 $0.31 \%(\mathrm{~V} / \mathrm{V})$ 로 재활용법적 기준치를 만족하였으며, 최대 약 $98.42 \%$ 까지 재활용이 가능한 것으로 평가되었다. 또한, 선별가연물의 경 우, 저위발열량이 약 $3,636 \mathrm{kcal} / \mathrm{kg}$ 으로 $\mathrm{RDF}$ 품질기준을 만족하였으며 최대 약 $84.43 \%$ 까지 $\mathrm{RDF}$ 생산이 가능한 것으로 측정되었다.

주제어 : 순환형매립지정비, 사용종료매립지정비, 고형연료, 선별시스템, 재활용

\begin{abstract}
potential assessment of converting closed non sanitary landfills into sustainable landfill through the reclamation works (= landfill mining project) of illegal landfill discovered in land development site using Sustainable Landfill Reclamation system(SLR-system) was investigated. The SLR system had treatment capacity of $91.4 \mathrm{~m}^{3} / \mathrm{hr}(130.61 \mathrm{ton} / \mathrm{hr})$ in condition of $28.0 \%$ of water content. Recovery ratio and purity of sorted soil were $98.9 \%$ and $99.66 \%$, respectively. Sorted combustibles were $91.8 \%$ and $92.0 \%$, respectively. Especially, high heating value (HHV) and low heating value(LHV) of combustibles were $4,282 \mathrm{kcal} / \mathrm{kg}$ and $3,636 \mathrm{kcal} / \mathrm{kg}$, respectively, in considering the energy content and recovery ratio of combustibles. Therefore, combustibles separated from landfill site have higher value than Fluff RDF standard value $(3,500 \mathrm{kcal} / \mathrm{kg}$ ) of MOE. RDF can be produced with combustibles by $84.43 \%$. Averaged size and organic foreign matter content of the sorted soil were less than $\varnothing 35 \mathrm{~mm}$ and $0.31 \%(\mathrm{~V} / \mathrm{V})$, respectively. In addition, concentration of all contents of hazardous matters containing soils met safety standards. Therefore, it is possible to be recycled as refilling and cover materials to rebuild Sustainable landfills by $98.42 \%$
\end{abstract}

Key Word : Sustainable Landfill Reclamation, Landfill minning, RDF, Sorting System, Recycling

\footnotetext{
† 2011년 9월 20일 접수, 2011년 11월 9일 1차수정

2011년 12월 2일 수리

*E-mail: forcebel@hanmail.net
}

\section{1. 서론}

2009년 현재 가정 등에서 발생되는 생활쓰레기량은 약 50,906톤/일로 2008년 약 52,072톤/일과 비교하여 약 $0.4 \%$ 증가추세이며, 이중 $18.6 \%$ 인 약 9,471 톤/일이 매립 처리되고 있다1). 매립은 일반적으로 설치부지면적 
이 넓고, 매립가스, 침출수 및 악취 등 다양한 2 차 환 경오염발생과 순환자원을 낭비한다는 지적에도 불구하 고, 처리방법이 간단하고, 소요경비가 적게 든다는 장점 등으로 인하여 전통적으로 생활쓰레기의 처리에 널리 적용되어 왔다. 2009년 말 기준 국내 217개소의 매립 장이 운영 중에 있으나 ${ }^{2)}$, 매립장 수명은 매립량 감소에 도 불구하고 수도권매립지를 제외할 경우 약 12 년 정 도로 예상되고 있다. 특히, 강원 영월 북면 매립장을 포 함한 49개의 매립장의 경우, 매립장 수명이 2년 이내로 매립장 수명이 종료될 것이 예상되어지나 ${ }^{2,3)}$, 신규매립 장 건설은 환경부의 자원순환 우선정책과 신규매립장 지원 축소 발표에 따라 많은 어려움이 예상되어 머지않 은 장래에 생활쓰레기 문제가 심각한 사회문제로 야기 될 수 있을 것으로 사료된다. 이에 따라 지역여건상 매 립이 반드시 필요하고, 가연물에너지화사업 우선 지원 대상에서 제외된 지역들을 중심으로 사용 중 이거나 사 용이 종료된 매립지를 지속적으로 사용 가능한 순환형 매립지로 전환하고 자 하는 요구가 국내뿐만 아니라 미 국, 일본과 동남아시아 등 여러 국가에서 증가되고 있 는 실정이다.

순환형매립지 정비기술(Sustainable Remediation Technology)은 사용 중이거나 사용이 종료된 매립지를 호기 성조건에서 악취제거 및 조기안정화한 후에 굴착, 기계 적 선별과정을 통하여 회수된 토사류 및 불연물류는 순 환형매립지(Bioreactor typed landfill)를 조성하는 건설 자재 및 복토재로 재활용하고, 가연물류는 현장에서 고 형연료(Fluff Typed RDF)를 생산하여 에너지 회수하는 과정을 통하여 매립지 공간을 확보고 이를 순환적 사용 이 가능한 매립지로 전환하는 매립지정비기술이다.

본 연구는 대전시 $\mathrm{OO}$ 권역 택지개발 지구내 발견된 비위생매립지를 정비하기 위하여 현장에 설치된 순환형
매립정비시스템(SLR-System, Sustainable ReclamationSystem, F사 제작)을 적용하여 기계적으로 토사류 및 가연물류를 순도 높게 선별분리하여 선별된 토사류의 경우, 순환형매립지 건설을 위한 성토재 및 복토재로 재 활용 가능한지, 또한 선별된 가연물류는 고형연료로 전 환하여 에너지 회수가 가능한지를 평가하였다.

\section{2. 실험재료 및 방법}

\section{1. 대상시료}

본 연구는 대전시 $\mathrm{OO}$ 권역 택지개발 공사과정에서 발 견된 비위생매립지를 대상으로 수행되었으며, 2002년 환경부 조사결과 매립지는 1983년 01월 1985년 02월 까지 매립이 진행된 것으로 보고되어졌다3). 대상 시료 는 $0.8 \mathrm{~m}^{3}$ 굴삭기로 비위생매립지 상부 복토 층을 제거 한 후 생활폐기물과 건설폐기물이 혼재되어 있는 매립 폐기물을 굴착하여 15 ton 덤프트럭에 실어 자동 계근 후 전량을 성능평가 및 환경성평가에 사용하였다.

SLR-System에서 선별 회수되어진 토사류 및 가연물 류는 $0.8 \mathrm{~m}^{3}$ 굴삭기로 혼합한 후 원추사분법으로 시료 를 일정량 채취하여, 재활용 가능성 및 에너지함량 평 가를 실시하였다.

\section{2. 실험장치}

본 연구에서 사용된 실험장치는 $\mathrm{F}$ 사에서 제작한 실 규모의 $80 \mathrm{~m}^{3} / \mathrm{hr}$ SLR-System을 이용하였으며, Fig. 1 과 같이 택지개발 지구내 설치하여 실험을 수행하였다.

SLR-System은 매립폐기물을 단계별로 기계적물리적 특성을 이용하여 토사류, 가연물류, 불연물류와 철재류 등으로 4원 선별할 수 있도록 제작·구성되었다. 본 연 구를 위하여 매립폐기물의 사전조사를 통해 폐기물의

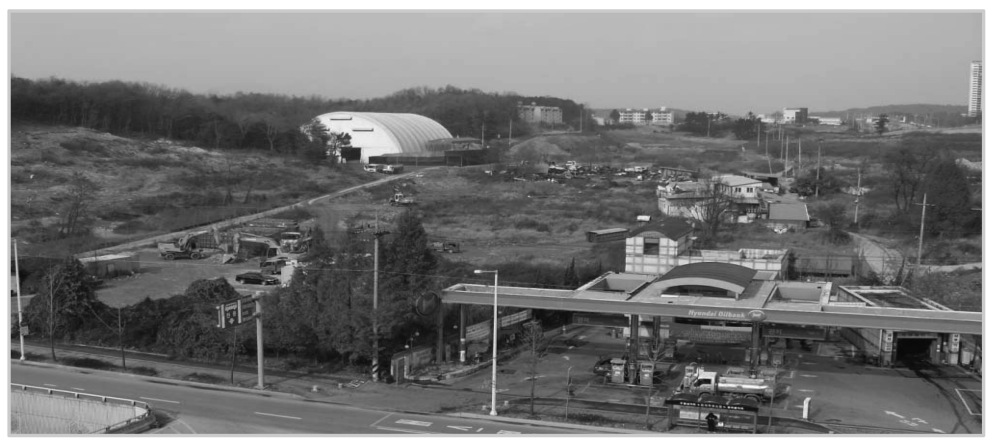

Fig. 1. Landfill reclamation project site using SLR-system. 


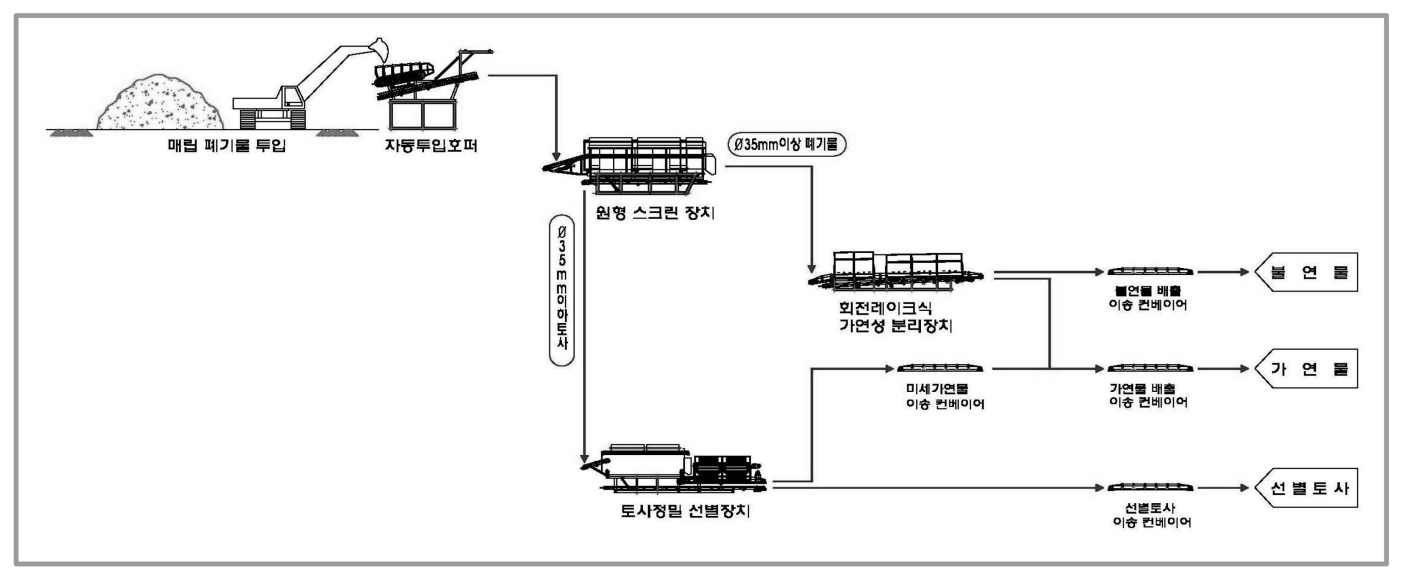

Fig. 2. Separation process of SLR-system used in landfill reclamation project site.

Table 1. Specifications of SLR-syste [Unit : mm]

\begin{tabular}{|c|c|c|c|c|c|c|}
\hline No & Device & Dimension $(\mathrm{W} \times \mathrm{H} \times \mathrm{L})$ & Capacity $\left(\mathrm{m}^{3} / \mathrm{hr}\right)$ & Weight $($ ton) & Electricity $(\mathrm{kW})$ & Type \\
\hline 1 & Automatic feeding hopper & $2,450 \times 3,200 \times 8,650$ & 80 & 10.5 & 13.00 & Slat conveyor \\
\hline 2 & Trommel screen & $2,560 \times 3,900 \times 8,800$ & 80 & 23.0 & 84.25 & Cylinder screen \\
\hline 3 & Combustible separator & $2,600 \times 3,180 \times 11,800$ & 60 & 15.0 & 25.75 & Rake \& brush \\
\hline 4 & Soil precision separator & $2,560 \times 3,900 \times 8,800$ & 60 & 18.0 & 35.50 & Cylinder screen+brush \\
\hline
\end{tabular}

물리적 성상과 최종선별물의 순도 및 회수율을 고려하 여 맞춤식으로 Fig. 2와 같은 공정을 구성하였다. SLRSystem 핵심 장치는 굴착된 매립폐기물을 정량공급하는 정량공급투입호퍼장치와 $\varnothing 35 \mathrm{~mm}$ 이하 토사를 분리하는 구멍막힘방지 칼날장착 트롬멜스크린장치, 가연성류를 기계식으로 선별회수하는 회전레이크식 가연물분리장치 그리고 트롬멜스크린에서 분리된 $\varnothing 35 \mathrm{~mm}$ 이하 회수된 토사류를 재활용 기준 $(\varnothing 100 \mathrm{~mm}$ 이하, 유기 이물질함량 부피비 $1 \%$ 미만)에 만족하게 선별하여 순도를 높이는 토 사정밀분리장치로 구성하였다.

SLR-System 공정을 구성하기 위하여 이용된 장치들 의 제원은 Table 1 과 같으며, 각 선별결과물의 회수율 및 순도에 가장 영향을 미치는 트롬멜스크린장치(토사 선별)는 체류시간과 선별효율 등을 고려하여 경사각 약 $7^{\circ}$, 트롬멜스크린회전속도는 약 $17 \mathrm{rpm}$, 칼날드럼은 약 $16 \mathrm{rpm}$ 로 설계제작하였고, 스크린의 회전방향과 직각방 향으로 3축으로 약 $150 \mathrm{~mm}$ Lifting bar를 설치하여 선 별 가연물류의 $\mathrm{RDF}$ 제조시 발열량의 저하 원인이 되어 지는 ${ }^{4)}$ 토사류 등 불활성물질의 선별효율을 극대화하였다. 도심지지역에서 수행되는 선별 작업시 소음 및 비산 먼지 등 환경오염 발생을 최소로 하기 위하여 약
$40 \mathrm{~m}(\mathrm{~W}) \times 70 \mathrm{~m}(\mathrm{~L}) \times 20 \mathrm{~m}(\mathrm{H})$ 규모의 truss dome을 건설 하고, truss dome 내부에 면적이 2 Set의 SLR-System 을 설치하여 비위생매립지 정비사업을 수행하였다.

본 실험은 이중 $1 \mathrm{set}$ 의 SLR-System을 사용하여 굴 착된 매립폐기물을 덤프트럭으로 이송하고 투입 및 선 별 과정을 거쳐 배출컨베이어로 truss dome 외부로 선 별물을 각각 이송 적치하였다.

\section{3. 실험방법}

2.3.1. 대상시료 분석

대상시료 분석은 겉보기밀도, 함수비, 물리적 조성, 삼 성분 등을 실시하였다. 겉보기 밀도 분석은 $75 \mathrm{~L}$ 플라스 틱용기에 시료를 채운 후 $30 \mathrm{~cm}$ 높이에서 수회 낙하한 뒤 감소된 만큼 시료를 추가하여 감소되지 않을 때까지 반복하고 그 무게를 측정하여 확인하였다. 물리적 조성 분석은 대상시료 전체를 분리판에서 수작업으로 7종의 가연성류(종이류, 비닐류, 음식물류, 고무류, 목재류, 기 타)와 4종의 불연물류(토사류, 금속류, 유리류, 기타) 등 11 종으로 분리하였다. 그리고 함수비는 KS F 2306 방 법, 삼성분 분석은 폐기물공정시험방법에 따라 수행하 였다. 
Table 2. Analytical methods

\begin{tabular}{|c|c|c|}
\hline Items & Detailed items & Analytical method \\
\hline \multirow{3}{*}{ 1. Performance assessment } & Capacity & -Weight analysis method \\
\hline & Recovery & Weight analysis method \\
\hline & Purity & Weight analysis method \\
\hline \multirow{2}{*}{ 2. Environmental assessment } & Flying dust & -Atmosphere analysis method ${ }^{+}$ \\
\hline & NoiseVibration & -NoiseVibration analysis method ${ }^{+}$ \\
\hline \multirow{2}{*}{ 3. Recycling assessmentt } & Soils & $\begin{array}{l}\text { - Leaching test: Waste analysis method }{ }^{+} \\
\cdot \text { Soil contamination test: Soil analysis method } \\
\text { - Organic foreign matter content: KS F } 2576\end{array}$ \\
\hline & Combustibles & $\begin{array}{l}\text { Physical composition : Waste analysis method }{ }^{+} \\
\text {Element : Mechanical analysis } \\
\cdot \text { Heating value : Dulong equation }\end{array}$ \\
\hline
\end{tabular}

주) + : Korean Standard Mothed

2.3.2. 실험장치 성능, 환경성 및 재활용성 평가

본 연구에서는 사용종료 비위생매립지를 SLR-System 을 적용하여 순환형매립지로 전환이 가능한지를 평가하 기 위하여 성능평가, 환경성평가 및 선별된 물질의 재 활용성평가를 수행하였다. 실험 방법은 약 $80 \mathrm{~m}^{3}$ 의 매 립폐기물을 굴착하여, 덤프트럭에 적재, 계량한 후에 현 장 Dome내 선별장으로 이송 적치하고 약 $0.8 \mathrm{~m}^{3}$ 굴삭 기로 전량을 SLR-System에 투입하여 5회에 걸쳐 성능 평가 및 환경성 평가를 진행하였다. 또한, 선별결과물의 재활용성 및 에너지 함량 평가를 위하여 Table 2와 같 이 물리적화학적 평가와 유해성 평가에 대한 정밀분석 실험을 수행하였다.

특히, SLR-System의 성능평가는 System내에 투입된 매립폐기물의 처리시간과 회수된 선별결과물 총량을 각 각 측정하여 평가하였다. 처리성능 $\left(\mathrm{m}^{3} / \mathrm{hr}\right)$ 은 투입량 $\left(\mathrm{m}^{3}\right)$ 을 처리시간(hr)로 나누어 산출하였으며, 회수율 $(\%)$ 은 선별된 성상별 총량 $(\mathrm{kg})$ 을 투입 전 성상별 총량으로 나 누어 산출하였고, 순도 $(\%)$ 는 선별된 성상별 총량에 대 한 이물질의 량을 함량으로 산출하였다. 또한, 회수된 가연물류는 향후 RDF(Refuse Derived Fuel)로 생산하 여 에너지화가 가능한지를 평가하기 위하여 원소분석자 료를 Dulong 공식에 적용하여 고위발열량 $\left(\mathrm{H}_{\mathrm{h}}\right)$ 과 저위 발열량 $\left(\mathrm{H}_{1}\right)$ 을 산출하였다.

\section{3. 실험결과 및 고찰}

\section{1. 대상매립지 폐기물 특성}

J. of Korean Inst. Resources Recycling Vol. 21, No. 1, 2012
Table 3. Bulk density of excavated landfill wastes $\quad\left[\mathrm{Ton} / \mathrm{m}^{3}\right]$

\begin{tabular}{|c|c|c|}
\hline Run No. & Bulk density & Water content(\%) \\
\hline 1st & 1.26 & 25.6 \\
\hline 2nd & 1.53 & 29.1 \\
\hline 3rd & 1.42 & 25.3 \\
\hline 4th & 1.47 & 32.3 \\
\hline 5th & 1.46 & 27.9 \\
\hline Avg. & 1.43 & 28.0 \\
\hline
\end{tabular}

택지개발과정에서 발견된 비위생매립지에서 폐기물을 굴착하여 매립폐기물의 특성을 분석한 결과, Table 3 과 같이 겉보기 밀도가 $1.26 \mathrm{ton} / \mathrm{m}^{3} \sim 1.53 \mathrm{ton} / \mathrm{m}^{3}$ 의 범위로서 평균 $1.47 \mathrm{ton} / \mathrm{m}^{3}$ 로 손 등5) 이 이전에 보고한 택지개발 지구의 매립폐기물 겉보기 밀도 약 $0.92 \sim 1.58 \mathrm{ton} / \mathrm{m}^{3}$ 중 건설폐기물이 주로 매립된 지역의 겉보기밀도와 유사하 며, 생활폐기물 대상 비위생매립장의 겉보기 밀도 $0.85 \sim 1.20 \mathrm{ton} / \mathrm{m}^{3}$ )에 비해서는 다소 높게 측정되어졌다.

또한, 원형선별장치 등 입도 선별장치의 분리 성능 및 효율에 가장 큰 영향을 미치는 수분함량은 약 $25.6 \%$ 약 $32.3 \%$, 평균 약 $28.0 \%$ 로 윤 등 7$)$ 이 조사 한 사용종료 5 년 미만의 비위생매립지의 수분함량 약 $21.6 \%$ 약 $36.6 \%$ 과는 유사한 결과 보였으나, 허 등6) 이 조사한 2000년 이전에 매립 종료된 비위생매립지의 수분함량 약 $31.2 \%$ 약 $51.2 \%$ 보다는 다소 낮게 측정 되었다. 이 분석 결과는 매립지 수분함량이 매립지 연 한보다는 매립지의 입지조건, 매립되어진 폐기물 성분 및 매립지의 운영방식에 따라 변화될 수 있음을 보여주 
Table 4. Physical composition of excavated landfill wastes [Unit : Wt.\%]

\begin{tabular}{|c|c|c|c|c|c|c|c|c|c|c|c|c|c|}
\hline \multirow{2}{*}{ Run No } & \multicolumn{8}{|c|}{ Combustibles } & \multicolumn{4}{|c|}{ Incombustibles } & \multirow{2}{*}{ Soil } \\
\hline & papers & Vinyls & Foods & Rudders & Woods & Textiles & other & sub-total & metals & glasses & other & sub-total & \\
\hline $1 \mathrm{st}$ & 0.00 & 2.62 & 0.00 & 0.77 & 0.40 & 0.85 & 0.17 & 4.81 & 0.02 & 6.40 & 1.08 & 7.51 & 87.68 \\
\hline 2 nd & 0.00 & 2.09 & 0.00 & 0.18 & 0.00 & 1.23 & 0.09 & 3.59 & 0.00 & 8.17 & 0.00 & 8.17 & 88.25 \\
\hline $3 \mathrm{rd}$ & 0.00 & 1.84 & 0.00 & 1.34 & 0.68 & 0.16 & 0.00 & 4.01 & 0.00 & 7.05 & 0.00 & 7.05 & 88.95 \\
\hline 4th & 0.00 & 2.41 & 0.00 & 0.97 & 0.45 & 0.78 & 0.08 & 4.69 & 0.04 & 4.47 & 1.46 & 5.97 & 89.34 \\
\hline 5 th & 0.00 & 2.14 & 0.00 & 0.92 & 0.41 & 0.69 & 0.04 & 4.20 & 0.00 & 10.16 & 0.00 & 10.16 & 85.64 \\
\hline Avg. & 0.00 & 2.62 & 0.00 & 0.77 & 0.40 & 0.85 & 0.17 & 4.81 & 0.02 & 6.40 & 1.08 & 7.51 & 87.68 \\
\hline
\end{tabular}

고 있다.

매립폐기물의 물리적 조성은 Table 4와 같이 토사류 가 평균 약 $87.68 \%$, 철재류를 포함한 불연물류가 약 $7.51 \%$, 에너지회수가 가능한 가연물류가 약 $4.81 \%$ 로 측정되었으나, 음식물류 등 생분해성 물질들은 거의 포 함되지 않는 것으로 측정되었으며, 이는 매립 후에 미 생물에 의하여 분해가 오랜 기간 진행된 결과로 사료된 다 5,8 .

Fluff RDF 등 에너지 회수대상인 가연물류의 경우, 기존에 보고된 택지개발지구내 비위생매립지의 가연물 류 함량 약 $0.81 \% \sim 3.96 \%{ }^{5}$ )와 유사하였으며, 박 등 ${ }^{4)}$ 이 보고한 생활폐기물 매립지의 가연물류 함량 약 39.97\%('99 ‘09, 매립진행), 약 57.25\%('02 ‘09, 매립 종료)에 비교하여 낮게 측정되었다. 이는 본 연구 대상 의 택지개발지구내 비위생매립지가 주로 건설폐기물 위 주 매립이 이루어진 결과로 사료된다.

성토재 등 재활용 대상인 토사류의 경우, 기존에 보고 된 사용종료매립지의 토사류 함량 약 35.30\%('99 '09, 매립 진행)과 약 $55.11 \%($ ('02 '09, 매립종료)에 비교하여 높게 측정되었다. 이는 매립폐기물 중 음식물, 종이, 목 재 등의 생분해성물질이 분해 안정화되어 복토재와 함 께 새로운 토사류로 형성되었으며, 초기에 매립된 주된 폐기물이 건설폐기물로서 플라스틱과 같은 난분해성물 질의 함량이 적었기 때문으로 판단된다 ${ }^{9}$.

특히, 토사함유율은 초기 매립량 및 매립지 안정화 기간과 상관관계를 가지므로 매립시간의 경과함에 따라 토사함유율은 지속적으로 증가될 것으로 예상된다. ${ }^{6,9)}$ 또한, 사용종료매립지의 토사함유율이 일반적인 경우 약 $50 \%$ 이상-6)으로 보고되고 있어 사용종료매립지를 순환형 매립지로 조성하기 위한 공간 확보를 위해서는 매립토 사류의 재활용이 반드시 필요한 것으로 사료된다.

매립폐기물의 삼성분은 Table 5와 같이 목재류의 수
분과 가연분이 각각 약 $24.5 \%$ 와 $52.7 \%$ 로, 고무류의 회분이 약 $36.1 \%$ 로 가장 높은 수치로 측정되었다. 특 히, 매립폐기물의 대부분을 차지하는 토사류는 수분이 약 $21.5 \%$, 가연분이 약 $2.6 \%$, 회분이 약 $75.9 \%$ 로 측 정되었다. 이는 김 등 ${ }^{2}$ 이 건설재료로의 재활용을 위한 강도와 안정적 처리 기준으로 제시된 유기물(가연분)함 량이 약 $4 \%$ 미만으로 측정되었으며, 환경부 사용종료 매립지정비지침 ${ }^{11)}$ 의 매립지 안정화기준에서 제시한 토 사내 가연분함량이 $5.0 \%$ 이내를 만족하였다. SLRSystem을 이용하여 토사내의 가연성 성분을 효율적으로 제거할 경우에 성토재 등 순환형매립지 건설재료로 사 용하기에 충분한 안정화 및 강도가 유지되어 현장재활 용이 가능할 것으로 사료된다.

\section{2. 성능평가}

사용 중이거나 사용이 종료된 매립지를 순환형매립지 로 전환하기 위해서는 사전 안정화 과정을 거친 매립폐 기물을 짧은 시간 내에 고효율로 선별 - 회수 할 수 있 는 기계적 시스템과 선별결과물을 용도에 맞게 재활용 하거나 에너지 회수하는 과정을 통하여 매립지 공간을 확보하고, 매립지 기능을 복원하여 순환적인 재사용이 가능도록 하는 것이 중요하다. 본 연구에서는 현재까지 매립폐기물 선별에 주로 사용되던 원형스크린과 풍력선 별장치의 성능저하 및 환경오염 문제 등 한계점을 극복 하기 위하여 스크린 막힘 방지 칼날이 장착된 원형스크 린과 기계식회전레이크를 적용하여 점성이 강한 토사의 스크린 막힘 현상과 가연물 회수 및 순도 저하를 개선 하였다. 특히, 기계소음과 비산먼지 등 환경오염을 최소 화하기 위한 커버를 설치한 후 성능평가를 수행하였다.

본 SLR-System의 성능평가 결과, Table 6과 같이 최대 수분함량 약 $32.0 \%$ 조건에서 시간 당 약 $82.47 \mathrm{~m}^{3} \sim$ 약 $100.00 \mathrm{~m}^{3}$, 평균 약 91.48(약 $130.61 \mathrm{ton}$ ) 
Table 5. Proximate analysis of separated combustibles [Unit : \%]

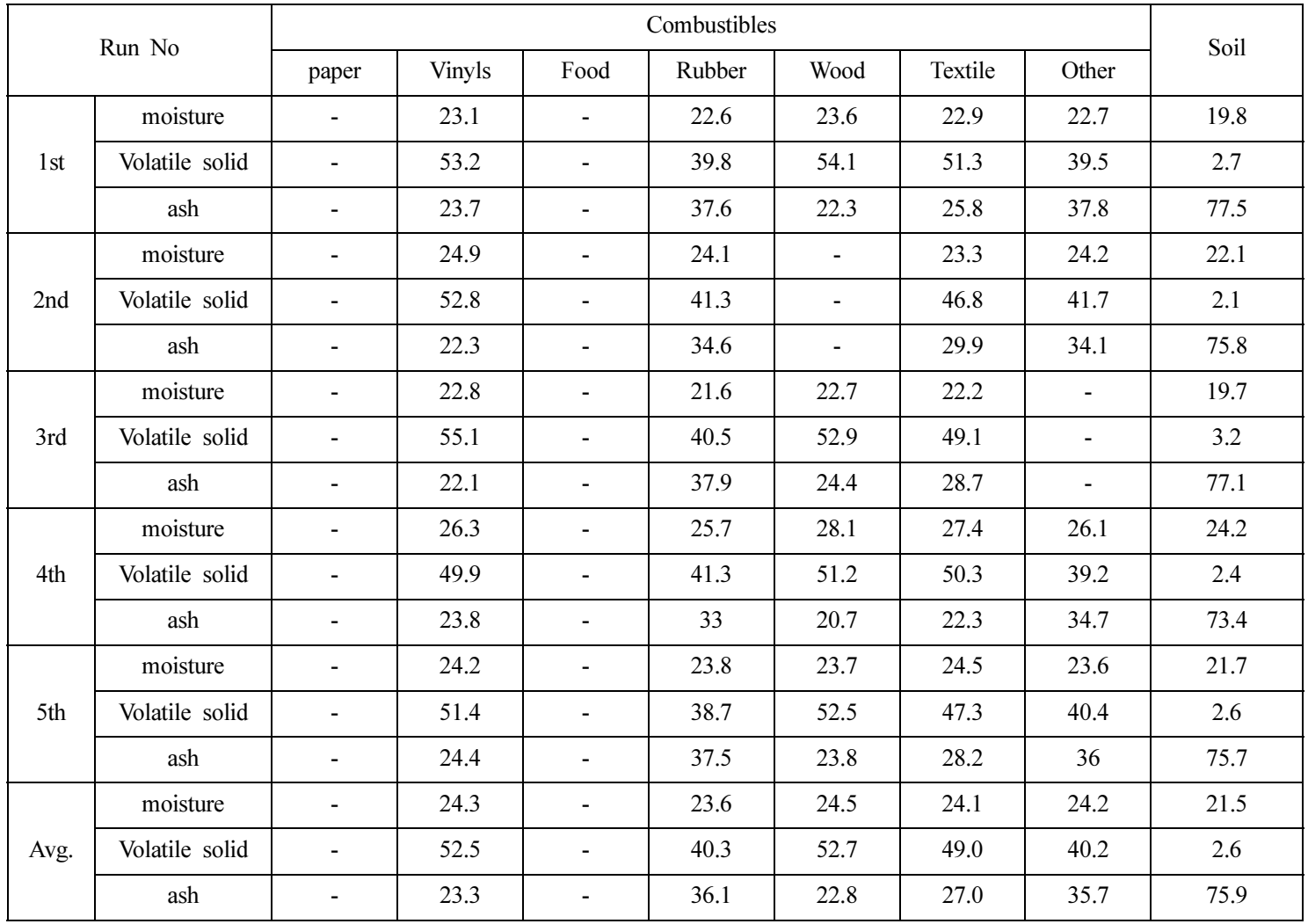

Table 6. Performance test of SLR-system

\begin{tabular}{|c|c|c|c|c|c|}
\hline \multirow{2}{*}{ Run No } & \multicolumn{2}{|c|}{ Input materials } & \multirow{2}{*}{ Operation time (min.) } & \multicolumn{2}{|c|}{ Throughput } \\
\cline { 2 - 3 } & $\mathrm{m}^{3}$ & ton & & $\mathrm{m}^{3} / \mathrm{hr}$ & ton/hr \\
\hline 1st & 80 & 100.45 & 55 & 86.02 & 108.01 \\
\hline 2nd & 80 & 122.74 & 58 & 82.47 & 126.54 \\
\hline 3rd & 80 & 113.44 & 48 & 100.00 & 141.80 \\
\hline 4th & 80 & 117.67 & 48 & 100.00 & 147.09 \\
\hline 5th & 80 & 116.65 & 53 & 88.89 & 129.61 \\
\hline Avg. & 80 & 114.19 & 53 & 91.48 & 130.61 \\
\hline
\end{tabular}

의 처리성능을 보여 수분함량 및 혼재도가 높은 상태로 매립지에 묻혀 있는 폐기물을 굴착운반하여 효과적으로 선별분리가 가능한 것으로 평가되었다.

SLR-System에 의하여 선별되어진 물질의 순도 및 회 수율은 매립폐기물의 에너지 및 재활용률을 결정하는 중요한 요소이다. 이를 측정하기 위하여 단계별 처리과 정에서 선별된 물질의 변화 및 성상을 측정하여 Fig. 3 과 같이 물질수지도를 작성하였다. 물질수지도에 의하
여 얻어진 값을 이용하여 계산된 선별토사의 회수율은 약 $98.86 \%$, 순도는 약 $99.56 \%$ 이며, 불연물류의 회수율 은 약 $91.90 \%$, 순도는 $96.98 \%$, 가연물류의 회수율은 약 $91.77 \%$ 순도는 약 $92.01 \%$ 로 높게 측정되었다.

특히, 매립폐기물의 약 $87.73 \%$ 로 대부분을 차지하는 토사의 경우, 최대 평균 약 $98.42 \%$ (=회수율×순도)까 지 회수하여 확보되어진 매립공간을 순환형매립지로 조 성하기 위한 성토재 및 복토재로 재활용이 가능하며, 약

J. of Korean Inst. Resources Recycling Vol. 21, No. 1, 2012 


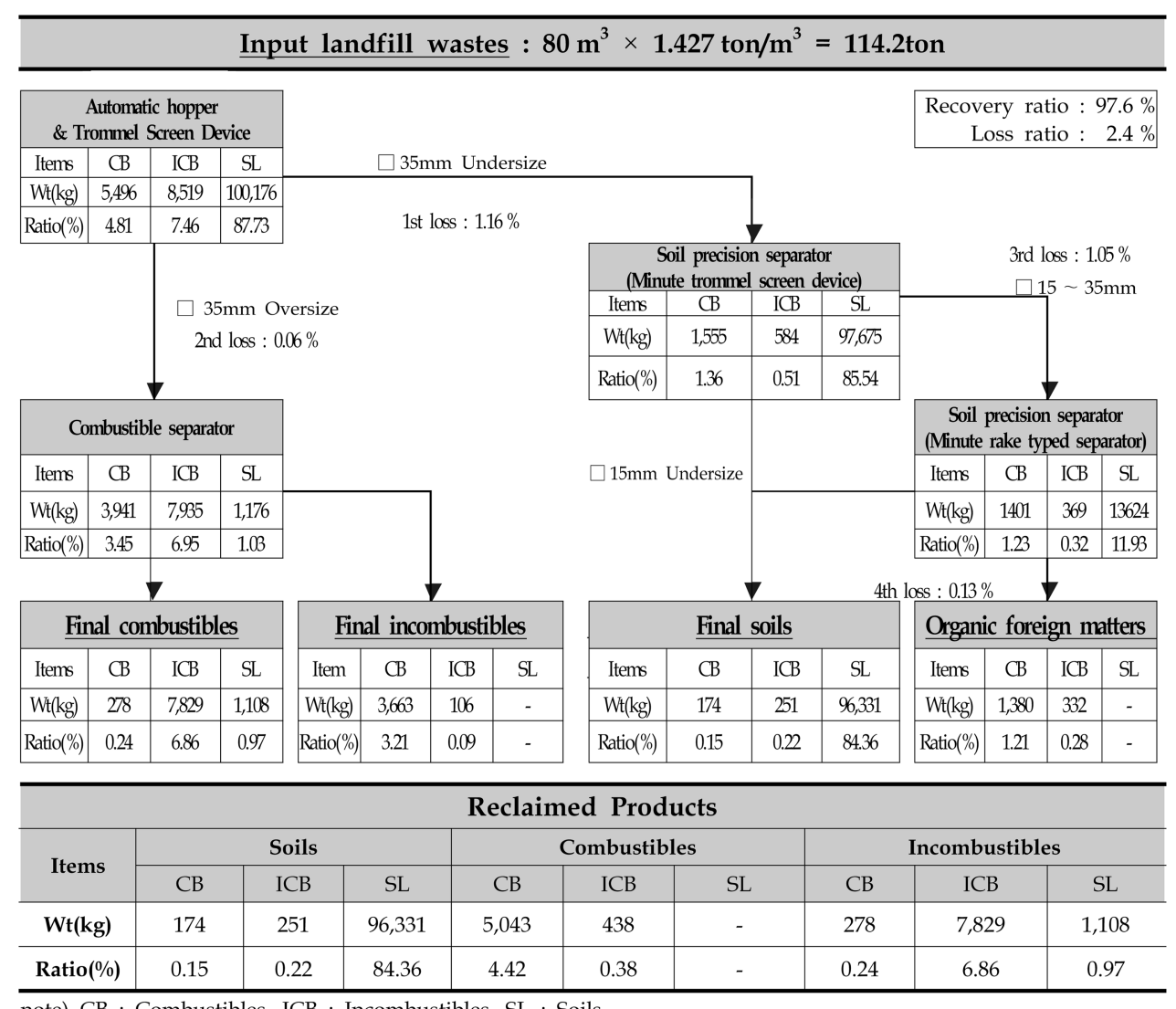

Fig. 3. Mass balance of FORCEBEL-SLR system.

$4.81 \%$ 를 차지하는 가연물류의 경우, 최대 평균 약 $84.43 \%$ 까지 회수하여 Fluff RDF 등으로 에너지회수 가능할 것으로 사료된다.

\subsection{SLR-System 의 현장 적용성 평가}

본 연구장치로 비위생매립장을 순환형 매립지로 전환 하는 경우, 예상되는 비산먼지(TSP), 소음 및 진동 등 2차 환경오염을 측정하여 작업장 환경, 작업자 위생 및 안전성 등 예상되어지는 영향을 평가하였다. 보다 정확 한 평가를 위하여 SLR-System부터 이격거리를 고려하 여 작업장(선별기의 $1 \mathrm{~m}$ 이격), 돔 경계지역(선별기의 $20 \mathrm{~m}$ 이격) 및 부지경계 지역(선별기의 $100 \mathrm{~m}$ 이격)의 3 곳을 선정하여 평가하였다.

연구결과 Fig. 4와 같이 주변지역의 환경오염영향은 SLR-System과 주변 측정지점 간의 이격거리에 따라 양 (+)의 상관관계를 보였다. 비산먼지의 경우, 측정지점별로 평균 약 $0.41 \mathrm{mg} / \mathrm{Sm}^{3}$, 약 $0.08 \mathrm{mg} / \mathrm{Sm}^{3}$ 및 약 $0.03 \mathrm{mg}$ /
$\mathrm{Sm}^{3}$ 이며, 소음의 경우 각각 평균 약 $83.5 \mathrm{~dB}(\mathrm{~A})$, 약 $74.0 \mathrm{~dB}(\mathrm{~A})$ 및 약 $46.5 \mathrm{~dB}(\mathrm{~A})$ 이고, 진동의 경우 모든 측 정지점에서 $0.0 \mathrm{~dB}(\mathrm{~V})$ 로 비산먼지, 소음 및 진동이 법적기 준치 이하로 측정되었다.

특히, Fig. 5와 같이 스크린 막힘방지 칼날이 장착된 트롬멜스크린장치는 기존 스크린막힘방지 화염버너 및 에어노즐이 장착된 트롬멜스크린과 비교하여 토사 회수 율을 크게 향상시켰으며, 화염, 검댕 등 2 차 환경오염 발생을 저감하는 역할을 하였다. 또한, 비산먼지 및 소 음 등 2 차 환경오염방지커버가 장착된 기계식회전레이 크장치는 기존에 주로 많이 적용되어지던 단순 풍력선 별에의한 가연물 선별과 비교하여 가연물회수율 및 순 도를 크게 개선하였다.

\section{4. 에너지함량 및 재활용성평가}

매립지 정비 과정에서 회수된 가연물류의 에너지 함 량과 토사류의 유기 이물질 함량을 측정하여 향후 순환 

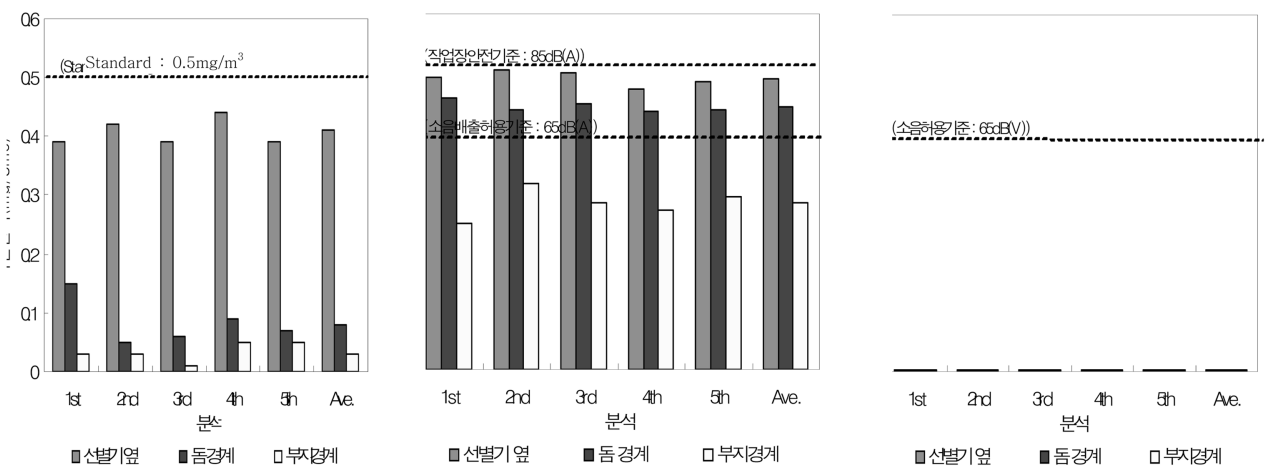

Fig. 4. Environmental assessment in working area.

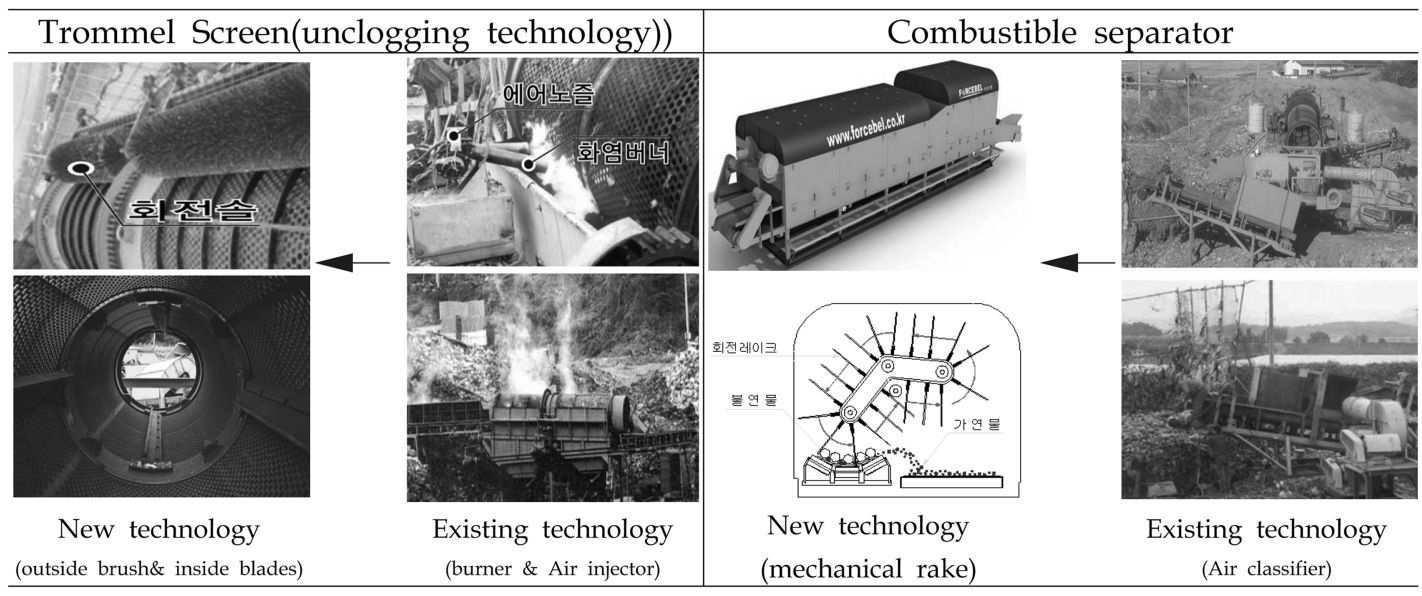

Fig. 5. Comparison of trommel screen and combustible separator between new technology and existing technology.

Table 7. Proximate analysis for recovered combustibles

\begin{tabular}{|c|c|c|c|c|c|c|c|}
\hline \multicolumn{2}{|c|}{ Run No } & $1_{\mathrm{st}}$ & $2_{\text {nd }}$ & $3_{\mathrm{rd}}$ & $4_{\text {th }}$ & $5_{\text {th }}$ & Avg. \\
\hline \multirow{3}{*}{ Wood } & moisture & 30.89 & 33.52 & 32.81 & 27.74 & 29.71 & 30.93 \\
\hline & volatile solid & 53.51 & 50.08 & 54.92 & 53.76 & 56.28 & 53.71 \\
\hline & ash & 15.60 & 16.40 & 12.27 & 18.50 & 14.01 & 15.36 \\
\hline \multirow{3}{*}{ Textile } & moisture & 28.47 & 26.55 & 27.33 & 24.81 & 26.48 & 26.73 \\
\hline & volatile solid & 66.07 & 65.15 & 67.74 & 68.21 & 67.43 & 66.92 \\
\hline & ash & 5.46 & 8.30 & 4.93 & 6.98 & 6.09 & 6.35 \\
\hline \multirow{3}{*}{$\begin{array}{l}\text { Vinyls } \\
\text { /plastic }\end{array}$} & moisture & 27.68 & 24.01 & 22.68 & 25.84 & 26.16 & 25.27 \\
\hline & volatile solid & 62.34 & 67.23 & 66.37 & 64.69 & 66.58 & 65.44 \\
\hline & ash & 9.98 & 8.76 & 10.95 & 9.47 & 7.26 & 9.28 \\
\hline \multirow{3}{*}{$\begin{array}{l}\text { Rudders } \\
\text { /Leather }\end{array}$} & moisture & 29.28 & 29.57 & 27.78 & 30.32 & 31.62 & 29.71 \\
\hline & Volatile solid & 57.14 & 55.93 & 54.32 & 58.21 & 55.81 & 56.28 \\
\hline & ash & 13.58 & 14.50 & 17.90 & 11.47 & 12.57 & 14.00 \\
\hline
\end{tabular}

J. of Korean Inst. Resources Recycling Vol. 21, No. 1, 2012 
Table 8. Element analysis for recovered combustibles

[Unit : \%]

\begin{tabular}{|c|c|c|c|c|c|c|c|}
\hline \multicolumn{2}{|c|}{ Run No } & $1 \mathrm{st}$ & 2nd & $3 \mathrm{rd}$ & 4th & 5th & Ave. \\
\hline \multirow{7}{*}{ Wood } & $\mathrm{C}$ & 42.32 & 46.72 & 45.82 & 46.41 & 46.38 & 45.53 \\
\hline & $\mathrm{N}$ & 0.06 & 0.07 & 0.08 & 0.09 & 0.08 & 0.08 \\
\hline & $\mathrm{H}$ & 5.97 & 6.65 & 6.28 & 6.06 & 6.03 & 6.20 \\
\hline & $\mathrm{S}$ & 0.07 & 0.09 & 0.08 & 0.08 & 0.07 & 0.08 \\
\hline & $\mathrm{O}$ & 43.28 & 41.09 & 42.81 & 43.42 & 41.76 & 42.47 \\
\hline & $\mathrm{Cl}-$ & 0.01 & 0.02 & 0.02 & 0.01 & 0.02 & 0.02 \\
\hline & Ash & 8.30 & 5.38 & 4.93 & 3.94 & 5.68 & 5.65 \\
\hline \multirow{7}{*}{ Textile } & $\mathrm{C}$ & 65.97 & 67.32 & 63.69 & 64.92 & 66.71 & 65.72 \\
\hline & $\mathrm{N}$ & 0.03 & 0.04 & 0.05 & 0.04 & 0.04 & 0.04 \\
\hline & $\mathrm{H}$ & 11.68 & 11.92 & 11.36 & 10.93 & 12.42 & 11.66 \\
\hline & S & 0.04 & 0.03 & 0.06 & 0.08 & 0.03 & 0.05 \\
\hline & $\mathrm{O}$ & 4.46 & 4.98 & 3.92 & 4.18 & 4.82 & 4.47 \\
\hline & $\mathrm{Cl}-$ & 0.01 & 0.02 & 0.01 & 0.01 & 0.02 & 0.01 \\
\hline & Ash & 17.82 & 15.71 & 20.92 & 19.85 & 15.98 & 18.06 \\
\hline \multirow{7}{*}{$\begin{array}{l}\text { Vinyls } \\
\text { /Plastic }\end{array}$} & $\mathrm{C}$ & 72.69 & 74.36 & 74.28 & 72.36 & 72.16 & 73.17 \\
\hline & $\mathrm{N}$ & 0.13 & 0.14 & 0.16 & 0.15 & 0.14 & 0.14 \\
\hline & $\mathrm{H}$ & 12.36 & 14.75 & 13.34 & 13.65 & 12.16 & 13.25 \\
\hline & $S$ & 0.21 & 0.16 & 0.28 & 0.19 & 0.24 & 0.22 \\
\hline & $\mathrm{O}$ & 1.53 & 1.39 & 1.36 & 1.48 & 1.53 & 1.46 \\
\hline & $\mathrm{Cl}-$ & 0.12 & 0.16 & 0.15 & 0.17 & 0.12 & 0.14 \\
\hline & Ash & 13.08 & 9.20 & 10.58 & 12.17 & 13.77 & 11.76 \\
\hline \multirow{7}{*}{$\begin{array}{l}\text { Rudders } \\
\text { /Leather }\end{array}$} & $\mathrm{C}$ & 56.46 & 52.93 & 53.91 & 51.86 & 54.36 & 53.90 \\
\hline & $\mathrm{N}$ & 0.89 & 0.85 & 0.79 & 0.83 & 0.76 & 0.82 \\
\hline & $\mathrm{H}$ & 8.79 & 8.33 & 8.51 & 9.23 & 8.93 & 8.76 \\
\hline & $\mathrm{S}$ & 0.09 & 0.13 & 0.16 & 0.11 & 0.12 & 0.12 \\
\hline & $\mathrm{O}$ & 13.69 & 12.71 & 13.82 & 13.84 & 14.36 & 13.68 \\
\hline & $\mathrm{Cl}-$ & 0.06 & 0.09 & 0.08 & 0.07 & 0.08 & 0.08 \\
\hline & Ash & 20.08 & 25.05 & 22.81 & 24.13 & 21.47 & 22.71 \\
\hline
\end{tabular}

형 매립지 정비 과정에서 발생되는 가연물류 및 토사류 의 활용 가능성을 평가하였다. 선별된 가연물류는 음식 물류와 종이류 등과 같이 쉽게 분해되는 물질들은 회수 되지 않았으며, 미생물분해에 의하여 무기화되었거나 해 리되어 토사류로 회수된 것으로 사료된다.

선별 가연물류의 경우, 삼성분과 원소분석 후 Dulong 공식을 적용하여 고위발열량과 저위발열량을 측정한 결 과 Table 7 8과 같이 고위발열량은 약 $4,191 \mathrm{kcal} / \mathrm{kg}$
약 $4,391 \mathrm{kcal} / \mathrm{kg}$, 평균 약 $4,282 \mathrm{kcal} / \mathrm{kg}$, 저위발열량은 약 $3,539 \mathrm{kcal} / \mathrm{kg} \sim$ 약 $3,739 \mathrm{kcal} / \mathrm{kg}$, 평균 약 $3,636 \mathrm{kcal} / \mathrm{kg}$ 로 높게 나타났다.

측정결과 윤 등9)이 보고한 음식물 직매립금지 후 충 북 $\mathrm{J}$ 시 도시생활폐기물 저위발열량 약 $3,565.6 \mathrm{kcal} / \mathrm{kg}$ 와 수도권 매립지로 반입되는 생활쓰레기의 발열량 약 $3,000 \mathrm{kcal} / \mathrm{kg}$ 약 $3,800 \mathrm{kcal} / \mathrm{kg}^{12)}$ 와 비교하여 보면 유사 한 수치를 보였다. 이 등13)이 보고한 매립혼합폐기 
Table 9. The Organic foreign matter content for recovered soil

[Unit: \%(V/V)]

\begin{tabular}{|c|c|c|c|c|c|c|c|}
\hline Run No & Standard & $1_{\text {st }}$ & $2_{\text {nd }}$ & $3_{\text {rd }}$ & $4_{\text {th }}$ & $5_{\text {th }}$ & Avg. \\
\hline Organic foreign matter & 1.0 & 0.32 & 0.29 & 0.15 & 0.31 & 0.50 & 0.31 \\
\hline
\end{tabular}

물(매립연한 1 7년)의 습윤기준 발열량 약 751 $1,305 \mathrm{kcal} / \mathrm{kg}$ 보다는 에너지함량이 높으나, 선별하여 가 연분만을 측정한 저위발열량 약 $5,850 \mathrm{kcal} / \mathrm{kg}$ 보다는 에 너지 함량이 다소 낮은 것으로 측정되었다. 이러한 결과 로부터 매립폐기물 중 가연물류의 에너지함량을 개선하 기 위해서는 기계적 선별공정이 필수적이며4), 회수된 가 연물류로부터 Fluff RDF의 품질 기준인 $3,500 \mathrm{~kg} / \mathrm{kcal}$ 이상인 Fluff RDF 제조가 가능할 것으로 사료된다. 특 히, 국내에서 생산되어지는 석탄은 대부분 무연탄으로 발 열량 $4,400 \mathrm{kcal} / \mathrm{kg}$ 이상은 가정용(십구공탄)제조용으로 $3,250 \mathrm{kcal} / \mathrm{kg}$ 이상의 저질무연탄은 화력발전용으로 수입석 탄과 혼합하여 사용되어지고 있는 실정으로 ${ }^{14)}$ 매립폐기 물 중 가연물류를 고순도로 회수할 경우 석탄의 대체연 료원으로써 시멘트공정 및 제지제조공정 뿐만 아니라 열 병합발전소 등 다양한 분야의 적용이 가능할 것으로 사 료된다.

에너지 기본법의 [에너지 열량 환산기준] 중 국내무 연탄 총발열량 약 $4,650 \mathrm{kcal} / \mathrm{kg}$ 과 IPCC의 탄소배출계 수 중 무연탄 석유환산계수 $0.465 \mathrm{TOE}$ 를 ${ }^{15)}$ 고려하여 선별회수된 가연물류 1 ton을 대체연료로 사용하였을 경 우 약 1.466ton $\mathrm{CO}_{2}$ 만큼 탄소배출 저감효과가 있을 것으로 사료된다.

본 연구에서는 선별 토사류의 용출시험, 토양오염도 시험, 입도 분석 및 유기 이물질 함량 분석을 통하여 성토재 및 복토재로서의 사용가능 여부를 법적 기준에 따라 평가하였다. 선별토사의 경우는 대부분 복토재와 연탄재 성분으로 구성되어 있으며, 매립연한에 따라 매 립폐기물 중 음식물, 종이, 목재 등의 생분해성물질이 분해되어 새로운 토양으로 형성됨으로써 안정화된 매립 지에서는 토사류가 차지하는 비율이 매우 높은 것으로 보고하고 있다. ${ }^{13)}$ 따라서, 선별토사류를 회수하여 복토 재 등으로 재활용하는 것은 사용이 종료된 비위생매립 지에 새로운 매립공간을 확보하고, 이를 순환적으로 사 용하기 위해 반드시 필요한 것으로 사료된다.

이 등13)은 기존 연구에서 선별토사 재활용을 위한 최 적 트롬멜스크린의 입경으로 $\varnothing 20 \mathrm{~mm}$ 를 제시하였으나 최소 스크린 막힘과 최대 회수율 등을 고려하여 본 연 구에서는 트롬멜스트린의 입경을 $\varnothing 35 \mathrm{~mm}$ 로 하여 설계 제작하여 회수된 토사류를 재활용기준인 $\varnothing 100 \mathrm{~mm}$ 이하
조건을 만족하도록 하였다. 이와 더불어 Table 9와 같 이 KF S 2579 방법으로 회수된 선별토사류 내 유기이 물질함량 분석 결과, 약 $0.15 \%$ 약 $0.50 \%$, 평균 약 $0.31 \%$ 이내로 재활용 기준인 (부피기준 $1 \%$ 미만)을 만 족하여 성토재 및 복토재 등으로 재활용이 가능한 것으 로 평가되었다.

또한, Table 10 11과 같이 선별된 토사를 재활용할 경우 발생할 수 있는 환경유해성 및 환경영향을 분석한 결과 모든 수치가 법적기준치 이하로 측정되었다.

매립지 토사류에 대한 이전 연구에서 이 등13)은 안정 화된 매립지 토사류는 유기독성물질 및 중금속에 대한 흡수능력이 탁월하며 일반토사와 비교하여 중금속 함량 이 높지만, 미국의 퇴비화 기준 농도보다는 낮아 재매립 시 중금속에 대한 문제가 발생하지 않을 것으로 보고하 였다. 또한, 김 등10)도 선별토사류의 환경유해성 및 환경 영향평가를 통하여 선별토사류는 $\mathrm{pH}$ 가 약 7.72 로 중성 상태이며, 토사의 유해성과 환경영향이 적고, 입도 균등 계수 $(\mathrm{Cu})$ 와 곡률계수 $(\mathrm{Cg})$ 가 $18.3,3.0$ 으로 양입도이며, 통 일분류법에서 $\mathrm{SW}$ 로 “입도분포가 좋은 모래질”로, AASHTO로는 “점토질이 섞인 모래질”로 분류되어 성토 재로 사용되는 일반적인 등급을 만족하는 것으로 보고 하였다. 최 ${ }^{16) ㄷ ㅗ ~ ㅇ ㅕ ㄱ ㅅ ㅣ ~ ㅅ ㅐ ㅇ ㅎ ㅘ ㄹ ㄱ ㅖ ㅍ ㅖ ㄱ ㅣ ㅁ ㅜ ㄹ ㅇ ㅣ ~ ㅁ ㅐ ㄹ ㅣ ㅂ ㄷ ㅚ ㄴ ~ ㅁ ㅐ ㄹ ㅣ ㅂ ㅈ ㅣ ㅇ ㅔ ㅅ ㅓ ~}$ 발생한 토사는 선별토사의 재사용에 따른 토양오염 발 생이 없으며, 일반토양과 혼합할 경우 토질공학적 안정 성에 유리한 것으로 보고하였으며, 양질 토사와 $50 \%$ 로 혼합하여 복토재 및 성토재로 사용 가능함을 밝혔다. ${ }^{10)}$

본 연구결과, 순환형매립지정비 과정에서 발생되어 선 별되어진 토사는 순환형매립지 조성을 위한 성토재 및 매립을 위한 복토재로 사용이 가능하며, 선별토사 재활 용에 따른 환경 유해성 및 환경영향이 적은 것으로 판 단된다. 특히, 매립폐기물 조성의 많은 부분을 차지하고 있는 선별토사류의 선별재활용은 순환형매립지 운영시 매립공간 확보차원에서도 상당한 효과가 있을 것으로 판단된다.

\section{4. 결 론}

대전시 $\mathrm{OO}$ 권역 택지개발 지구내 비위생매립지정비공 사에 순환형매립지정비시스템(SLR-System)을 이용하여 
Table 10. the leaching tests for recovered soil

[Unit : mg/L]

\begin{tabular}{|c|c|c|c|c|c|c|c|}
\hline Run No & Standard & $1_{\text {st }}$ & $2_{\text {nd }}$ & $3_{\text {rd }}$ & $4_{\text {th }}$ & $5_{\text {th }}$ & Avg. \\
\hline $\mathrm{Pb}$ & 3 & 0.03 & N.D. & 0.02 & 0.02 & N.D. & 0.014 \\
\hline $\mathrm{Cu}$ & 3 & 0.400 & 0.016 & 0.017 & 0.033 & 0.035 & 0.100 \\
\hline $\mathrm{As}$ & 1.5 & 0.112 & N.D. & 0.006 & 0.011 & N.D. & 0.026 \\
\hline $\mathrm{Hg}$ & 0.005 & N.D. & N.D. & N.D. & 0.0013 & N.D. & 0.001 \\
\hline $\mathrm{CN}$ & 1 & N.D. & N.D. & N.D. & N.D. & N.D. & N.D. \\
\hline $\mathrm{Cr}+6$ & 1.5 & N.D. & N.D. & N.D. & N.D. & N.D. & N.D. \\
\hline $\mathrm{Cd}$ & 0.3 & N.D. & N.D. & N.D. & N.D. & N.D. & N.D. \\
\hline Org.P & 1 & N.D. & N.D. & N.D. & N.D. & N.D. & N.D. \\
\hline $\mathrm{PCE}$ & 0.1 & N.D. & N.D. & N.D. & N.D. & N.D. & N.D. \\
\hline $\mathrm{TCE}$ & 0.3 & N.D. & N.D. & N.D. & N.D. & N.D. & N.D. \\
\hline Oil $(\mathrm{Wt} \%)$ & 5 & 0.026 & 0.022 & 0.015 & 0.028 & 0.033 & 0.025 \\
\hline
\end{tabular}

Table 11. The soil contamination analysis for the recovered soil

[Unit : $\mathrm{mg} / \mathrm{kg}$ ]

\begin{tabular}{|c|c|c|c|c|c|c|c|c|}
\hline \multicolumn{2}{|c|}{ Run No } & Standard & $1_{\text {st }}$ & $2_{\text {nd }}$ & $3_{\mathrm{rd}}$ & $4_{\text {th }}$ & $5_{\text {th }}$ & Avg. \\
\hline \multicolumn{2}{|c|}{$\mathrm{Cd}$} & 1.5 & 0.088 & 0.052 & 0.129 & 0.049 & 0.088 & 0.081 \\
\hline \multicolumn{2}{|c|}{$\mathrm{Cu}$} & 50 & 6.194 & 1.983 & 4.297 & 3.535 & 2.183 & 3.638 \\
\hline \multicolumn{2}{|c|}{$\mathrm{Pb}$} & 100 & 5.78 & 2.77 & 6.96 & 3.29 & 5.46 & 4.852 \\
\hline \multicolumn{2}{|c|}{$\mathrm{Zn}$} & 300 & 92.0 & 71.1 & 173 & 91.0 & 108 & 107.02 \\
\hline \multicolumn{2}{|c|}{$\mathrm{Ni}$} & 40 & 5.98 & 7.26 & 17.8 & 9.45 & 9.60 & 10.02 \\
\hline \multicolumn{2}{|c|}{$\mathrm{Cr}^{+6}$} & 4 & 0.178 & 0.072 & N.D. & N.D. & N.D. & 0.05 \\
\hline \multicolumn{2}{|c|}{$\mathrm{CN}$} & 2 & N.D. & N.D. & N.D. & N.D. & N.D. & N.D. \\
\hline \multicolumn{2}{|c|}{$\mathrm{Hg}$} & 4 & 0.0679 & 0.0233 & 0.2269 & 0.1660 & 0.3678 & 0.170 \\
\hline \multicolumn{2}{|c|}{ As } & 6 & 1.389 & 0.625 & 3.250 & 1.239 & 1.545 & 1.610 \\
\hline \multicolumn{2}{|c|}{$\mathrm{F}$} & 400 & N.D. & N.D. & N.D. & N.D. & N.D. & N.D. \\
\hline \multicolumn{2}{|c|}{ Org.P } & 10 & N.D. & N.D. & N.D. & N.D. & N.D. & N.D. \\
\hline \multicolumn{2}{|c|}{ PCB } & - & N.D. & N.D. & N.D. & N.D. & N.D. & N.D. \\
\hline \multicolumn{2}{|c|}{ Phenol } & 4 & N.D. & N.D. & N.D. & N.D. & N.D. & N.D. \\
\hline \multirow{2}{*}{ Oil } & BTEX & - & N.D. & N.D. & N.D. & N.D. & N.D. & N.D. \\
\hline & ТPH & 500 & 12 & N.D. & 11 & 36 & N.D. & 11.8 \\
\hline \multicolumn{2}{|c|}{ TCE } & 8 & N.D. & N.D. & N.D. & N.D. & N.D. & N.D. \\
\hline \multicolumn{2}{|c|}{ PCB } & 4 & N.D. & N.D. & N.D. & N.D. & N.D. & N.D. \\
\hline
\end{tabular}

매립폐기물을 기계식으로 선별분리하여, 회수된 선별결 과물을 현장에서 재활용 하거나 에너지화 하는 과정을 통하여 사용종료 매립지를 순환적 사용이 가능한 매립지 로 전환이 가능한지 평가하였으며 결론은 다음과 같다.

1. 실험대상 비위생매립폐기물의 특성은 겉보기밀도 가 평균 약 $1.47 \mathrm{ton} /$, 수분함량이 약 $28.0 \%$ 이며, 물리적성상의 경우, 토사류가 약 $87.68 \%$, 불연물 류가 약 $7.51 \%$, 에너지회수가 가능한 가연물류가
약 $4.81 \%$ 이다. 특히, 음식물류 등 유기물류함량이 매우 적게 측정되어 매립 후 상당기간 미생물분해 가 진행된 것으로 사료된다.

2. 실험장치의 성능 평가결과, 최대 수분함량 약 $32.0 \%$ 에서 시간 당 약 $91.48 \mathrm{~m}^{3}$ (약 130.61 ton)로 측정되었다. 선별물의 회수율과 순도는 각각 선별 토사의 경우, 약 $98.86 \%$ 와 약 $99.56 \%$, 불연물류 의 경우, 약 $91.90 \%$ 와 약 $96.98 \%$, 가연물류의 
경우, 약 $91.77 \%$ 와 약 $92.01 \%$ 로 높게 측정되었 다. 특히, 선별토사의 경우, 최대 약 $98.42 \%$ 까지 회수되어 재활용이 가능 하며, 가연물류의 경우, 최대 약 $84.43 \%$ 까지 회수하여 Fluff RDF 등으로 전환이 가능할 것으로 사료된다.

3. 현장 작업시 작업장 주변에서 발생 예상되는 환경 오염 강도는 이격거리와 양(+)의 상관관계를 가지 며, 비산먼지가 약 $0.03 \mathrm{mg} / \mathrm{Sm}^{3} \sim 0.41 \mathrm{mg} / \mathrm{Sm}^{3}$, 소음이 약 $46.5 \mathrm{~dB}(\mathrm{~A}) \sim 83.5 \mathrm{~dB}(\mathrm{~A})$, 진동이 모든 조건에서 $0.0 \mathrm{~dB}(\mathrm{~V})$ 로 모두 법적기준치 이하로 측 정되어졌다.

4. 선별결과물의 에너지함량 및 재활용성 평가결과, 선 별된 가연물류의 저위발열량(HLV)이 약 $3,636 \mathrm{kcal} /$ $\mathrm{kg}$ 로 Fluff RDF의 품질기준인 이상으로 에너지함 량이 높은 것으로 측정되었으며, 선별된 가연물류 1 ton을 대체연료로 사용하였을 경우 약 1.466 ton $\mathrm{CO}_{2}$ 만큼 탄소배출 저감효과가 있는 것으로 측정되 었다. 또한, 선별된 토사류는 입경이 약 $\varnothing 35 \mathrm{~mm}$ 이 하이고, 유기이물질함량 약 $0.31 \%$ (부피비)이내로 재 활용 품질기준을 만족하였으며, 유해성 등 환경영 향평가 결과 모든 수치가 법적 기준치를 만족하여 선별된 토사를 순환형매립지정비사업을 위한 성토 재 및 복토재로 사용할 수 있는 것으로 사료된다.

\section{사 사}

본 연구는 환경부의 차세대에코이노베이션기술개발사 업의 지원으로 수행하고 있는 “이동식 매립지 정비 및 선별 가연물 연료화 기술 실증” 통합 연구과제중 하나 입니다. 본 연구를 지원해 주신 모든 관계자 여러분께 감사드립니다.

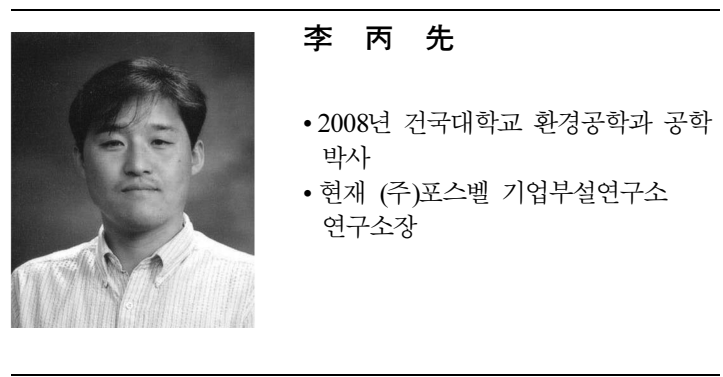

\section{참고문헌}

1. 환경부, 2010: 2009년 전국폐기물발생 및 처리현황.

2. 환경부, 2010: 2009년 전국 생활폐기물 매립시설 운영현황.

3. 환경부, 2002: 전국 사용종료매립지 기초조사 결과 및 관 리대책.

4. 박진규, 송선호, 이남훈 외 2 명, 2009: 굴착폐기물의 $\mathrm{RDF}$ 활용가능성에 관한 기초적 연구, 2009년도 추계학 술발표회 논문집, pp. 395 397, 한국폐기물학회.

5. 손영규, 박범국, 임명희 외 2명. 2008: 택지개발 현장내 비위생매립지의 매립쓰레기 처리방안 연구, 한국환경과학 지 17(2), pp. 177-183, 한국환경과학회.

6. 환경관리공단, 2002: 사용종료매립지 유형별정비지침 수 립 및 정비사업추진체계 개선방안에 대한 연구.

7. 윤석표, 윤범한, 1997: 비위생매립지의 굴착, 선별, 재활용 에 관한 사례연구, 한국폐기물학회지 14(6), pp. 541-547, 한국폐기물학회.

8. 조한상, 임정대, 김재영, 2003: 비위생매립지의 안정화 평 가를 위한 기초 조사, 한국폐기물학회지 20(5), pp. 470477, 한국폐기물학회.

9. 윤석표, 2008: 음식물폐기물 정책변화가 도시생활폐기물 의 조성변화에 미치는 영향, 유기성자원학회지 16(1), pp. $39-45$, 유기성자원학회.

10. 김정훈, 이재영, 나경덕, 이병선, 2004: 사용종료매립지 선 별토사의 재활용을 위한 기초연구, 한국폐기물학회 추계 학술연구회발표 논문집, pp. 442 445, 한국폐기물학회.

11. 환경부, 2002 : 사용종료매립지정비지침.

12. 수도권매립지관리공사, 2006: 가연성폐기물 고형연료(RDF) 의 경제성 분석 및 제도도입에 관한 연구.

13. 이남훈, 윤석표, 김철중, 1995 : 폐기물 매립지 재사용을 위한 매립폐기물의 물리화학적 특성에 관한 기초연구, 한 국폐기물학회지, 12(5), pp. 525-533, 한국폐기물학회.

14. 강석호, 1998 : 21세기의 에너지와 산업사회, 영남대학교 출판부.

15. 김태현, 2007: 수도권 이산화탄소 배출량 산정과 저감 방 안을 위한 교재개발의 필요성, 한국교원대 교육대학원 석

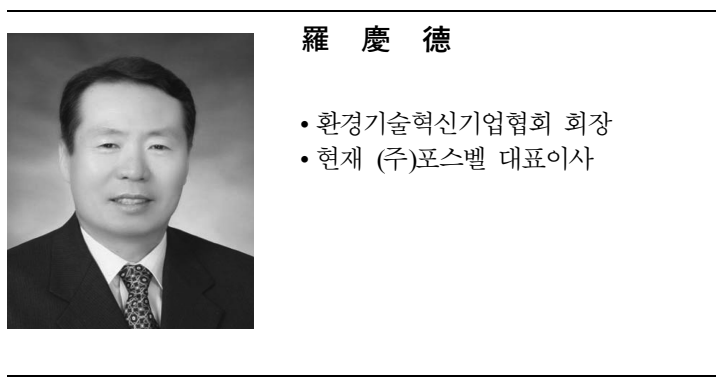

사학위논문. 

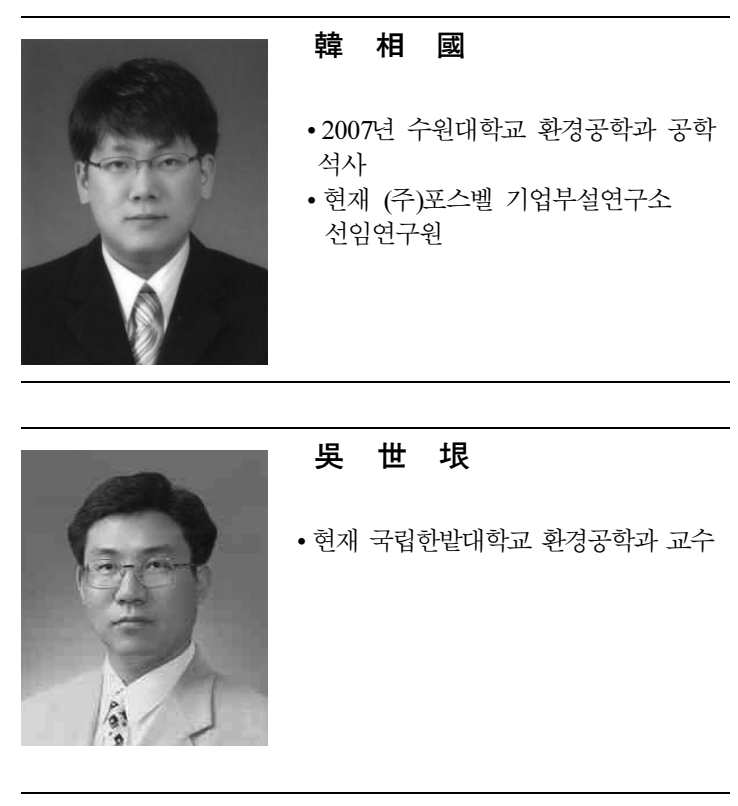

16. 최재규, 2005: 폐기물 매립지선별토사의 물리화학적특성
袈 在 根

• 현재 서울과학기술대학교 환경공학과 교수

연구, 서울시립대학교 석사학위논문. 